\begin{tabular}{|l|c|c|c|}
\hline ACTA CLASSICA & LII. & 2016. & \\
UNIV. SCIENT. DEBRECEN. & & & pp. 117-134. \\
\hline
\end{tabular}

\title{
TROPES AND FIGURES AS ARGUMENTS IN TEXTUAL CRITICISM?
}

\author{
(A FEW REMARKS ON ST GREGORY OF NYSSA'S \\ FIRST HOMILIES ON THE FORTY MARTYRS OF SEBASTE)*
}

\author{
BY JUDIT D. TÓTH
}

\begin{abstract}
In the first part of my paper, I present the so-called first homilies of St Gregory of Nyssa delivered in praise of the forty martyrs of Sebaste (Mart Ia and Ib) from two separate angles: on the one hand, focusing on how they can be related to stays of the Cappadocian Father in Sebaste and, on the other hand, identifying what sorts of internal arguments of textual criticism are cited when an effort is made to identify when they were delivered. By giving an overview of the most important research findings, I provide a basis for my query concerning whether certain tropes and rhetorical figures as well as rhetorical-stylistical-poetical solutions could be typical of specific time periods and genres in the oeuvre of the church father and, thereby, serve as arguments of textual criticism for identifying the dates for composition of his works. Using the opening lines of Mart $I b$, I focus my investigation on the banquet-simile connected to the figure of yesterday/then and today/now, primarily in the epideictic speeches of the bishop of Nyssa. My conclusion is that this is a valid question, while the text analyses confirm the conventional date (383) identified for the production of Mart Ia and $I b$.

Keywords: St Gregory of Nyssa; First Homilies on the Forty Martyrs of Sebaste (Mart Ia, $I b)$; Tropes and figures as internal arguments in textual criticism; Banquet-simile.
\end{abstract}

In the research of the works of early church fathers, exactly like in the case of all texts in fact, besides the authentic critical editions of the text sources under scrutiny, the chronological data of the life and works of the given authors and a reliable clarification of these may be considered an important precondition, or point of departure, for text interpretation. As a matter of course, this also happens to be true in the case of Gregory of Nyssa, whose life was never recorded either in a biography or an encomium by any of his contemporaries, unlike in the case of his brother, St. Basil the Great, about whom both their common friend, St. Gregory of Nazianzus, and Nyssenus himself wrote. As Anna Silvas notes in her preface to the collection of letters, "[his] surviving works are not as rich in autobiographical passages" as, for example, the letters of Basil or

doi $10.22315 / \mathrm{ACD} / 2016 / 9$ 
the poems of Nazianzen. What is more, "often in the personal testimonies that do survive Gregory manages to reveal himself and yet remain somehow elusive." 1

In spite of all the above factors, the (chronological) investigations concerning his life, activities, and works began relatively early, in the $1700 \mathrm{~s}^{2}$ However, the point of departure for the more recent chronological assumptions was the excellent Jean Daniélou study (1955), which intended to clarify the dates of the speeches, ${ }^{3}$ on the basis of which Jean Bernardi (1968), ${ }^{4}$ Gerhard May $(1971),{ }^{5}$ Pierre Maraval ${ }^{6}$ and others made additional comments and statements. The research efforts were also closely influenced by the vivid chronological disputes in the 1980s and 1990s concerning the life and activities of Basil, ${ }^{7}$ which seemed to be the last and conclusive of such issues raised for quite some time, although this obviously does not mean that the authors afterwards would fail to make any assumptions about the dates while they were examining the individual pieces and topics. This latter attitude is well exemplified by the recent comprehensive overviews of the life and works of the church father, like, for example, The Brill Dictionary, ${ }^{8}$ or the study written by Anna Silvas to accompany the English-language publication of the letters mentioned above. ${ }^{9}$ Essentially, these efforts confirmed the earlier findings, at least with regard to the most important events and dates. Even Pierre Maraval, who had surveyed and summed up the entire issue in an article published in 2004, was inclined later to withdraw a few of his earlier suggestions which had been considered rather surprising by many. ${ }^{10}$

In this paper, my objective is to examine the first homily (Mart Ia and $I b)^{11}$ presented by Gregory of Nyssa on two consecutive days in Sebasteia, Armenia, in praise of the forty martyrs of the city so that I could see whether the text of

*This paper is the edited version of the talk delivered at the 12th Conference of the Hungarian Society for Ancient Studies (May 26-28, 2016).

${ }^{1}$ Silvas 2007, 1 .

${ }^{2}$ For early research, see May 1971, 51-67.

${ }^{3}$ Daniélou 1955, 346-372; and Daniélou 1966.

${ }^{4}$ Bernardi 1968.

${ }^{5}$ May 1971, 51-67.

${ }^{6}$ Maraval 1990, 15-80.

${ }^{7}$ Cf. Silvas 2007, 33.

${ }^{8}$ Mateo-Seco - Maspero 2010

${ }^{9}$ Silvas 2007, 1-58.

${ }^{10}$ Maraval 2004, 153-157.

${ }^{11}$ [Encomium] In XL Martyres Ia, In XL Martyres Ib. GNO X 1/2 137-142, 145-156. All references to the sermons (including other works by Gregory, wherever it is possible) are made on the basis of the critical editions of Gregorii Nysseni Opera (GNO), in the conventional way. For the English translation, see: Leemans 2003, 91-110. 
the panegyric of the Cappadocian Father can offer further text parts in addition to or beyond the arguments of internal textual criticism raised previously by former research that can be taken into consideration from the aspect of a dating query, or perhaps some poetic-rhetorical-stylistic solutions which can be used as additional arguments in the dating dilemmas of the text.

My propositions, which affect methodological issues also from a theoretical perspective, are directed primarily to the homilies mentioned above exactly because these belong to the very few of the works of Gregory the dating efforts of which have been subject to more recent and even more surprising hypothesizing. Johan Leemans, for example, has proposed a theory ${ }^{12}$ concerning Mart $I a$ and $I b$ as related to the stay of the bishop of Nyssa in Sebaste to introduce an interpretation which is different from the previous consensus. It clearly illustrates that, while we continue to be uncertain about unknown or lesser-known time periods of the life of the Cappadocian Father, even the formerly established dates are sometimes subjected to reconsideration or review. The new postulates generate further questions: on the one hand, what could still serve as grounds for posing new hypotheses and, on the other hand, whether these new hypotheses would prove to hold water at all.

If, for a premise, we set out to consider all the different assumptions to be correct, we need to suppose at least three stays in Sebaste by Gregory. The first assumed, but never really proved, stay is connected to his exile, following the Synod of Ancyra in 375, where he was charged with embezzlement of church property. ${ }^{13}$ There is an apparent consensus among researchers about the fact that the charges may have been made up, and it was really his brother, Basil, who was indirectly attacked through the person of Gregory and was in fact supposed to be the real target of accusations coming from Demosthenes, the vicar of the 'Pontic' diocese. The latter, in turn, must have been urged to commit this act of mudslinging by Eustathius of Sebasteia, who was an old friend of the family of Gregory. As a consequence of the charges, Gregory was then deposed, banished, and went into exile (winter of 375/76-378), but we do not know where. Johan Leemans supposes that it was as early as this point in time, around 376-78, that he first ended up in Sebaste. The basis upon which Leemans believes this assumption to be correct is the remark about the inscriptions

\footnotetext{
${ }^{12}$ Leemans 2001, 93-97.

${ }^{13}$ For a reconstruction of the lesser known period, see primarily the letters of Basil $(225,231$ 232, 237, 239) and comments. Cf.: Silvas 2007, 31-39. Another source could be Vita Sanctae Macrinae 21, where Gregory mentions his exile by Emperor Valens (GNO VIII, 1 393, 26-394, 4.)
} 
of psalms in the first homily of the bishop of Nyssa on the forty martyrs,${ }^{14}$ the discussion of which I would wish to return to at some later stage.

Anna Silvas, however, argues rather convincingly that, during the time of his exile, Gregory must have probably gone rather to the southern parts of the area, in order to get out of the vicar diocese of Demosthenes. If the expression 'beyond the border' (hyperioros) in letter 231 by Basil is a reference to this state of affairs, we definitely need to discredit the truth value of a stay in Sebaste at that time as proposed by Leemans. ${ }^{15}$

Gregory returned from his exile, wherever he must have spent it, sometime around the end of the summer or beginning of the autumn of 378, as his banishment had been lifted by emperor Valens back in the spring of that year and, following the death of the latter (on August 9, 378), his successor, Gratian even issued an edict of tolerance to restore Gregory to his bishopric. For some time afterwards, various events in his personal life (first, the death of Basil, then, the death of Macrina, his sister) kept Gregory away from Nyssa. However, when he returned and, finally, would have had a chance to focus on his own agenda in the church, either at the very end of 379 or the very beginning of 380, a delegation from the city of Ibora in the region of Pontos was sent to him to ask him to enter their local election for the position of bishop in order to ensure the victory of the Neo-Nicenes through his authority. ${ }^{16}$ While still in Ibora and working on this mission, he received another group of envoys from Sebaste at the end of February 380, who had a similar request. The stakes at this latter election were much higher, partly because Sebaste was a capital city, and also because the previous bishops there (Eulalius and Eustathius) had been hostile towards the Nicenes.

The fact of staying in Sebaste at the beginning of 380 seems undoubtable by now, so much so that Gregory was surprised to find that he himself got elected finally, as it is written in his letter $19(19,13,15-16)$. This letter depicts the situation Gregory found himself in Sebaste quite plastically, while it also turns out that, in fact, he was in custody, which he experienced as a sort of Babylonian Exile, on top of the fact that he had a really low opinion on the Armenian people $(19,17-18) .{ }^{17}$ Gregory's words in the letter surely read harsher than they should have been, but they also display that he did not feel good and tried to do his best to leave the city dubbed Babylon soon after the events mentioned

\footnotetext{
${ }^{14}$ Leemans 2001, 96-97; and Leemans 2010a, 483-484.

${ }^{15}$ Silvas 2007,32 .

${ }^{16}$ The most important source of the events is letter 19 by Gregory: cf. Silvas 2007, 43-44. For a publication of the letters, see Maraval 1990; Silvas 2007, 172-181. Additional important details are contained in letters 5, 10, 12, 18, 22: cf. Silvas 2007, 60-61.

${ }^{17} \mathrm{Cf}$. Oration 43 of Gregory of Nazianzus (Or 43, 17).
} 
above, sometime around the beginning or the middle of 380 , only to put his brother, Peter, instead of himself into the bishop's chair later. ${ }^{18}$

According to a general consensus, Gregory visited the Armenian capital city only one more time, at the beginning of March 383, when he was invited by Peter, his brother. One of the first significant measures taken by Peter was to have the relics of Peter I, a former bishop of Sebaste, brought back into the city, supposedly, at the beginning of the same year. Gregory's brother then decided to establish a holiday in honour of his predecessor, commemorating the dies memorabilis of the city, connected to the Feast of the Forty Martyrs, whose cult had been initiated exactly by his predecessor in the bishop's cathedra. He intended all this to be a symbolic manifestation of old unity in faith, so he invited his brother, Gregory, to give an address on the Day of the Forty. Part of his plan may have been to fortify his own authority through this ${ }^{19}$ which, now that we know the preliminaries, can also be seen as the objective of the Nyssen, too, together with the endeavour to strengthen faith and to put an end to dissension.

An important source to confirm the proof of this second visit to Sebaste is the homily which Gregory preached on the holy day of the forty military martyrs (Mart Ia és $I b),{ }^{20}$ which he was given in two instalments, on March $9^{\text {th }}$ and $10^{\text {th }}$. The venue for the first part was the edifice called martyrion, whereas the second part was delivered in a local church building, since his first attempt was interrupted by the loud noise produced by the crowd. ${ }^{21}$ An interesting and somewhat puzzling feature in this respect is the convention of publication, which traditionally identifies the former homily, delivered in Caesarea on March 9,379, to be the second and the latter, performed on March $9^{\text {th }}$ and $10^{\text {th }}$, 383 , to be the former one, which would support the theory and argumentation of Johan Leemans.

\footnotetext{
${ }^{18}$ Cf. Meredith 2003, 28.

${ }^{19}$ Silvas 2007, 50, 108 .

${ }^{20}$ Another homily of the bishop of Nyssa about the forty martyrs is also known ([Encomium]In XL Martyres II = Mart II): GNO X 1/2 159-169. According to Jean Daniélou (and others), Mart II was delivered on March 9, 379, in Caesarea: Daniélou 1955, 347-349; Mateo-Seco Maspero 2010, 165. Gregory must have stayed in the city at that time because of the death of his brother, Basil, and the oration was given in the Martyrion of the Forty, where his brother used to preach about the martyrs before. Cf. Silvas 2007, 40; Mühlenberg 2012, 115-134, 123-127. The 379 homily is an important document supporting the fact that homage to the Forty played a very important part in the private memory of Gregory's family, too. Cf. Mart II GNO X, 1/2 167; and Macr 34, 15-16. (GNO VIII, 1 408, 12-13). Cf. Mateo-Seco - Maspero 2010, 104-105; and Silvas 2007, 6, 40.

${ }^{21}$ The interruption of the delivery of the homily in this case does not seem to be just a rhetorical topos but more like a real life event, the multiple reasons for which could be traced in the text of the homily; however, I cannot elaborate on these in the framework of this paper.
} 
With regard to arguments in interior text criticism, establishing a date for "First Encomium on the Forty Martyrs of Sebaste" basically relies on three parts or remarks. One of these does not seem to be problematic at all: the address was given on an especially cold day towards the end of winter (Mart Ib GNO X, 1/2 152, 19. 21. 22), during the fasting period before Easter, irrespective of which year that happened to be. Gregory mentions this close to the end of the text, when he refers to the fact that the involvement of the audience in the suffering of the military martyrs: for those present "this the prelude to Easter;

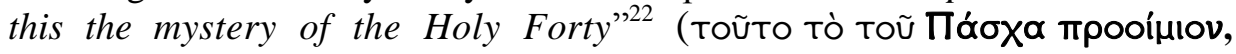

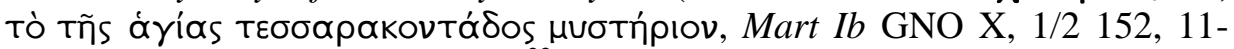
12) (may) mean the days of fight. ${ }^{23}$ It is at this point of the text that the bishop of Nyssa also evokes the chief narrative elements of the story of the Holy Forty still present in local memory: the frozen lake, the young soldiers' naked exposure, the clinging together of those condemned to freezing to death, the horrible bodily symptoms of the process of dying, the agony that lasted for three days, the burning of the bodies, and the moving act of the mother of the youth who still showed signs of life (Mart Ib GNO X, 1/2 153, 3-155, 2).

The other two remarks in the homily though pose several questions to consider. Right at the beginning of Gregory's text, there is a reference to the Holy Scripture, which is frequently brought up as an argument, since it contains the name of the apostle Peter, too (Mart Ia GNO X, 1/2 137, 7-14). This, according to certain argumentation patterns, might mean that Gregory delivered the speech with his brother, Peter, who was at that time already the bishop of the city, ${ }^{24}$ present in the crowd, and the event might be connected to what he had arranged as a bishop. ${ }^{25}$ The part in the original text is as follows:

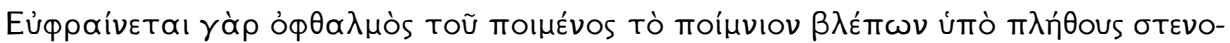



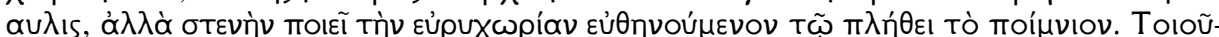

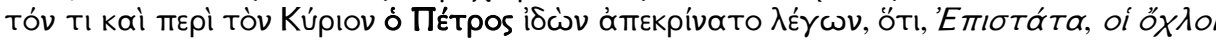

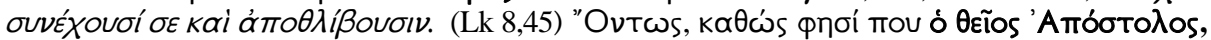

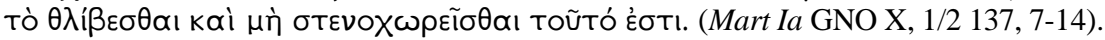

(Yes, the shepherd's eye rejoices at the sight of his flock that due to its large number is straitened and overflows its pen. And yet the sheep's fold isn't small but it is the thriving flock that by its large number makes the large space constricted. Surely it was a similar crowd that Peter had seen

\footnotetext{
${ }^{22}$ Trans. Leemans 2003, 103.

${ }^{23}$ The symbolic number referring to the mystery of Easter at this point of the homily is connected to the number of the martyrs (Mart Ib GNO X, 1/2 152, 12-15). (The symbolic meaning of this number is also available in Hungarian folk tradition. See Bálint 1977, 245.)

${ }^{24}$ Mateo-Seco - Maspero 2010, 165.

${ }^{25}$ Silvas $2007,50$.
} 
near the Lord when he reacted: 'Master, the multitudes surround you and press upon you' (Luke 8:45). Truly, it is as the divine Apostle says somewhere, 'being pressed upon' but not 'straitened'.) (Trans. Leemans 2003, 93)

However, upon a closer look at the respective text section, we may notice that the remark is embedded in a series of biblical examples and, for that reason, it could be rather a reference to a disciple of Jesus than to Gregory's junior brother. The point is that, in the section discussed, Gregory immediately transforms the spectacle of his discernibly large audience to an image of biblical origin (Mart Ia GNO X, 1/2 137, 5-11), which may remind us of another location in the Scripture: the crowd that presses around Jesus in the story of the woman who had been suffering from bleeding for twelve years $(\operatorname{Lk} 8,45)$ (Mart Ia GNO X, 1/2 137, 11ff.), in which the "Apostle of God" is also present. If there is an actual reference in the text to Peter, Gregory's brother, that could appear to be the result of a conscious play by Nyssenus on the double reference in the name, combining the biblical and the actual current situation into one.

Right after this part in the text (that is to say, still at the beginning of the homily), Gregory starts listing questions and dilemmas about his worries concerning which part of the Bible he could use as the best point of departure for exploring the mysteries that are beyond human understanding (Mart Ia GNO X, $1 / 2137,15){ }^{26}$ Among the examples he mentions (Mart Ia GNO X, 1/2 137, 9138,8 ), we also find a reference to psalms, and the comment on this is generally interpreted as an allusion to his piece of explicating psalm inscriptions, In Inscriptiones Psalmorum (Insc):

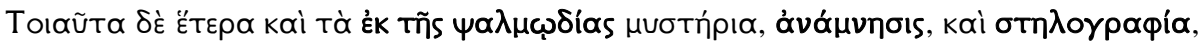

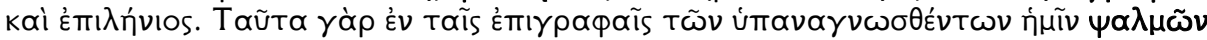

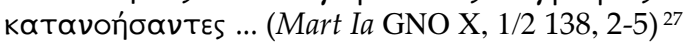

(Other similar instances are the mysteries of the Psalms: the remembrance, the inscription on a stone, the winepress. Indeed, in the reflection on these expressions in the inscriptions of the Psalms which were read aloud to us [...]) (Trans. Leemans 2003, 94)

Gregory's In Inscriptiones Psalmorum is thought to date back to $376-378,{ }^{28}$ and it is taken into consideration in the efforts of establishing a date for the first homily on the forty martyrs. Jean Daniélou supposes that the piece was known

\footnotetext{
${ }^{26}$ The biblical starting point for the oration will probably be the sentence citing the fourth of the Ten Commanments (Ex 20,12) in apostle Paul's epistle to the Ephesians (Ef 6,2-3).

${ }^{27}$ For the occurrence of the words anamnesis=memory, remembrance, stelography $=$ inscription in stone, and epylenios $=$ wine press in psalms, see Leemans 2001, 94. and Leemans 2003, 108. n. 11 .

${ }^{28}$ Cf. Leemans 2001, 96; and Leemans 2010a, 483-486.
} 
at the time of delivering the homily, which he dates back to the time period of the great fast in $383 .^{29}$ Johan Leemans - while also using the supposed date of Insc as a point of departure, but considering it terminus ante quem from the aspect of the homily - proposes that the date of delivery for Mart Ia and $I b$ was around 375, when he thinks Gregory was in Sebaste in exile, as I have mentioned this assumption above. In his line of argument, not only the above text part but also its direct continuation (and broader context: Mart Ia GNO X, 1/2 $137,19-138,16)$ also play an important part, where Gregory promises a second occasion for explicating psalm inscriptions, which, for Leemans, suggests the writing of In Inscriptiones (although the expression itself can also be a reference to homily as well): ${ }^{30}$

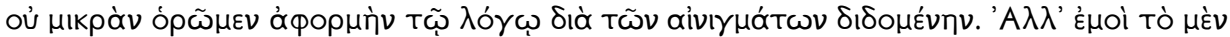

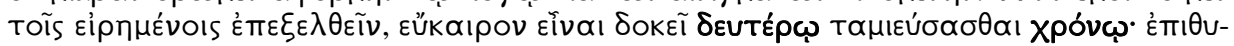


(Mart Ia GNO X, 1/2 138, 5-8)

([...] because of the riddles we see given no small resource for the homily. But I think it is better to come back to these words at a more opportune moment and to store them up for a second time. Because now I want to find a text that is fitting and appropriate for the present celebration.) (Trans. Leemans 2003, 94)

To sum up the above, we might say that neither the mention of Peter, nor that of the psalm inscriptions, used as internal textual arguments, would stand on firm foundations with respect to establishing a date for the delivery of the homily, while both of them can be used for justifying two contradictory assumptions at the same time.$$
* * *
$$

It was during the course of examining First Homilies on the Forty Martyrs of Sebaste (Mart $1 a, 1 b$ ) from a different aspect ${ }^{31}$ that the issue of whether an investigation of the rhetorical-poetical-stylistical solutions in the texts could contribute to the effort of finding answers to the questions of identifying the relevant date of production emerged. I wondered if it could be helpful in specific research projects on chronological dilemmas if we came across similar figures of speech, language patterns and expressions or even trains of thought
\end{abstract}

\footnotetext{
${ }^{29}$ Daniélou 1955, 362-363; Bernardi 1969, 303 and others also opt for 383. For an overview of the standpoints concerning potential dates, see Leemans 2010a, 483-486.

${ }^{30}$ For the detailed argumentation, see Leemans 2001, 93-97.

${ }^{31}$ D. Tóth 2016, 409-422.
} 
in texts that are considered close to one another not only in time but also in regard to displaying comparable or analogous features concerning genre specifications. Or is it perhaps a case of certain rhetorical and prose poetical solutions belonging not to epochs but to individual situations or, even more likely, to genres in the oeuvre of the bishop of Nyssa?

As a matter of course, the examination of rhetorical-stylistical elements and the rhythm of the prose in the works of Gregory is not a novelty. As far as I know, the most thorough instance of such an investigation to date is still a 1987 analysis by Christoph Klock, ${ }^{32}$ whose primary goal, however, is not to pay attention to the examples inspected for purposes of date identification. Others have also noted Gregory's refined style and way of writing determined by the rhetorical legacy of the Second Sophistic movement: how he prefers figures of speech, similes, and metaphors, while his texts also contain the largest number of ekphrastic descriptions among those of his contemporaries. ${ }^{33}$ Despite the fact that he often alludes to concrete and specific circumstances in his orations (for example earthquake - Pulcher GNO IX, 1 461, 8. 11. 18, 462, 24. 25, 463, 1; harsh Pontic winter - Mart Ib GNO X, 1/2 152, 19. 21. 22), his style frequently moves beyond the quotidian and becomes more sophisticated.

As I have mentioned above, Gregory had to interrupt the delivery of his homily on March $9^{\text {th }}$ because of the noise generated by the crowd in Sebaste. The homily that was continued the following day, on March $10^{\text {th }}$, in a different church building at a different location, (Mart Ib) opens with a rhetorical figure much preferred by Gregory, which is the confrontation of the time(frame)s of yesterday and today, and with the changing (metaphorical) image of providing a banquet: it is the martyrs that gave a banquet for the listeners yesterday, whereas it is the members of the audience who would need to reciprocate this hospitable treatment today.

The relevant passage in the homily runs as follows:

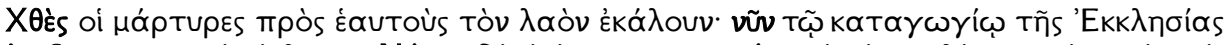

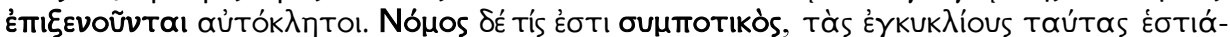

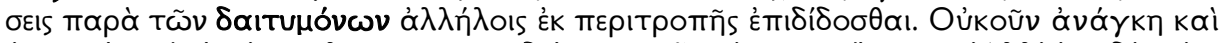





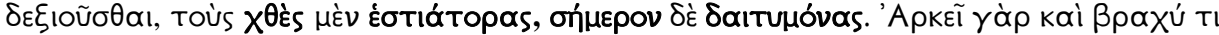


$\lambda \varepsilon i ́$ a vov ñ. (Mart Ib GNO X 1/2 145, 5-13)

\footnotetext{
${ }^{32}$ Klock 1987.

33 Among others: Leemans 2005, 109-129, with further references; Silvas 2007, 165, Leemans 2010b, 12-13.
} 
(Yesterday the martyrs called the people to them; now, on their own invitation, they are entertained as guests in the inn of the Church. In hospitality it is customary that these banquets circulate in the sense that the guests give them in return to each other in a rotating order. Accordingly we must give the martyrs the same banquet in exchange for their feast. But since our supply of words falls short, it is best that we receive those who were yesterday our hosts and are today our guests with the remains of their own reception. For even a small share of a richly-laden table is enough to prepare a great feast, when the remains are of this kind.) (Trans. Leemans 2003, 98)

Literary critics consider the banquet-metaphor in this case to be in association with real-life hospitality: the feast continued with a meal, which was no longer gruesome. ${ }^{34}$ Gregory's wording in this case may actually be connected to the shift in location, as it was the martyrs that "gave a banquet" on March $9^{\text {th }}$ for the audience present in the martyrion built in their honour, while it was the members of the ecclesia that did the same in a different church building on March $10^{\text {th }}$ (Mart Ib GNO X 1/2 145, 5ff.). In my opinion, there is much more to this than that, even if we cannot doubt the validity of the real-life details or motifs. ${ }^{35}$ The forced shift of location on the second day could have evoked other opening images in Gregory's rhetorical memory, so we may not necessarily consider it a mere coincidence that his choice fell on the banquet-simile.

I do not regard it necessary in this case to list the incidental associations triggered by the tradition of Greek and Roman feasts (symposion), even despite the fact that, on the one hand, we know that the bishop of Nyssa possessed the relevant professional knowledge, ${ }^{36}$ while on the other hand, the mechanism of action at Christian feasts and banquets displays a lot of similarities with that of "pagan" feasts and banquets. However, as opposed to the latter, the former lacked certain cultural content components (like poetry or philosophy, for example), and others (for example, singing) appeared to have different functions. ${ }^{37}$ (For similar reasons, I will not detail the New Testament locations that can be regarded as precedents either: Matthew 22,1-4; Luke 14,12-24; John 2,1-11.) In the similes of the Cappadocian Father, the purpose and experiences of the Christian banquets are evoked: including the act of grace received in the framework of a social gathering, the gesture of love finding expression in offering a banquet or a feast, the identity-forging effect of being in the company of others, and the duality of a regulated ritual frame versus the liberty of becoming a part of it. For Christians, banquets normally occur as events during the course

\footnotetext{
${ }^{34}$ Limberis, 2011, 23-24. "These festivals were not lugubrious occasions!" - Limberis cites Delehaye. Ib., 25. n. 76.

${ }^{35}$ Cf. Leemans 2005, 116: "Gregory of Nyssa compares the panèguris and his homily to a banquet",

${ }^{36}$ Cf. Alexander 1976, 56, 60-61.

${ }^{37}$ Study of Greek and Roman banquets is also regarded by many as a key factor in getting to know the real nature of culture in ancient times. Cf. Murray 1994.
} 
of which they ascend from the quotidian routine to the observance of festive occasions, while sharing the experience of equality and togetherness. As a consequence of this, there can be a range of different meanings associated with the invocation of banquets as metaphoric images, while their use as tropes, at least in theory, might be typical of certain specific authors.

In what follows, it is my intention to investigate where else, apart from the text of Mart Ib, the metaphorical images of banquets and feasts ${ }^{38}$ are present in a set of extant texts, more specifically, in panegyrics that belong to the circle of epideictic speeches (encomium) and in eulogies and funeral orations (epitaphios, oratio funebris), especially when they are connected with the rhetorical figures of the contrast/dichotomy of yesterday and today or then and now. The extant speeches of Gregory of Nyssa delivered in these genres are also relatively close to one another chronologically: ${ }^{39}$ consider the homily commemorating the forty martyrs in Caesarea (March 9, 379), ${ }^{40}$ the oration performed on the anniversary of the death of his brother Basil (January 1, 381), ${ }^{41}$ the martyrial encomium on the Holy Martyr Theodore held in Euchaita (February 7, $381),{ }^{42}$ the funeral eulogy of Meletius pronounced on the bishop's death in Constantinople (June, 381 ) ${ }^{43}$ the funeral speeches in honour of the members of the imperial house, Pulcheria and Flacilla, also given in Constantinople (August $25,385$, and October 14,385$),{ }^{44}$ as well as the two addresses praising protomartyr Stephen (December 26 and 27, 386). ${ }^{45}$ The question is if, based upon the chronological proximity of the speeches, we can make a "theoretical" presumption implying that certain images, similes, metaphors, and rhetorical solutions (for example, prooemia) are more typical of a certain time period in the life of the bishop of Nyssa than they would be characteristic of another life period.

In Gregory's speeches listed above, there are but few examples of the banquet-metaphor connected to the dichotomy of yesterday and today. The closest

\footnotetext{
${ }^{38}$ For a list of occurrences of related words, see the relevant volumes of Lexicon Gregorianum: von Mann 1999-2014.

${ }^{39}$ I rely on the summary by Pierre Maraval regarding the times of their deliveries: Maraval 2010, 163-165.

40 [Encomium] In XL Martyres II - Mart Ib GNO X, 1/2 159-169.

${ }^{41}$ In Basilium fratrem - Bas GNO X, 1/2 109-134.

${ }^{42}$ In Sancto Theodoro - Theod GNO X, 1/2 59-73.

${ }^{43}$ Oratio funebris in Meletium episcopum - Melet GNO IX, 1 441-457.

${ }^{44}$ Oratio consolatoria in Pulcheriam - Pulcher GNO IX, 1461-472; Oratio funebris in Flacillam imperatricem - Flacill GNO IX, 1 475-490.

${ }^{45}$ In Sanctum Stephanum I - Steph I GNO X, 1/2 75-94; In Sanctum Stephanum II - Steph II GNO X, 1/2 97-105.
} 
instance would occur at the beginning of the first address in praise of the Holy Protomartyr St. Stephen:



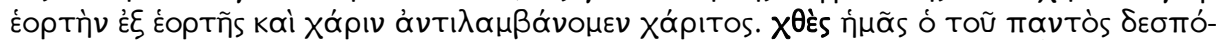

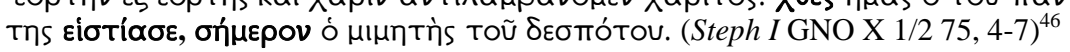

(How lovely is the inspiration exhibited by those who are good, and how sweet is the joy which they disclose! See, we acquire a feast from a feast and grace from grace. Yesterday the Lord of the universe welcomed us whereas today it is the imitator [Stephen] of the Lord.) (Trans. http://www.documentacatholicaomnia.eu/04z/z 0330-0395_Gregorius_Nyssenus Two Homilies_Concerning_Saint_Stephen_EN.doc.html)

In the passage cited, although he does not use the attribute spiritual (pneumatikos), ${ }^{47}$ Gregory evidently chooses the notion of banqueting to mean the graces provided by the holy day. ${ }^{48}$ However, the metaphor of the banquet, in a way similar to the structure in Mart $1 \mathrm{~b}$, serves only as an opening image to create the symbolic situation, never to return for the rest of the speech but to be replaced by the metaphors of stadium and battle and by agonistic language. In the second address (Steph II), it is only at the level of allusion that the notion of "spiritual banquet" (pneumatike hestia) appears (Steph II GNO 98, 10), related to the figure of protomartyr Stephen, who provides this for those in need of it.

Another potential example seems to be the opening passage of the funeral eulogy delivered in Constantinople on the untimely death of Bishop Meletius:



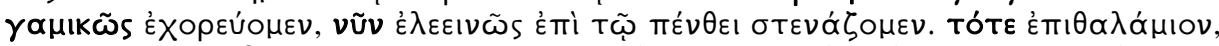
vũv É

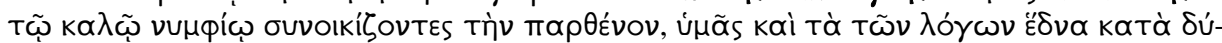

\footnotetext{
${ }^{46}$ The introductory part also cites the opening line of In Basilium fratrem, referring to the






der manner God has established an order [taxis] and sequence [akolouthia] by the feasts we commemorate each year. For example, today we have already celebrated a feast and will mark this same observance at a later time.) (Trans.

http://www.documentacatholicaomnia.eu/04z/z_03300395 Gregorius_Nyssenus_A_Eulogy_For_Basil_The_Great_EN.doc.html) IX, 1331,4

${ }^{47} \mathrm{Cf}$. De deitate adversus Euagrium (Vulgo In suam ordinationem oratio) - Deit Euag GNO

${ }^{48}$ Despite of the use of the opening image, it is still the Second Homily on Stephen (Steph II) that may be considered to be more of a festal sermon; "less panegyrical and more liturgical" - as Johan Leemans contends, see Leemans 2010b, 10.
} 


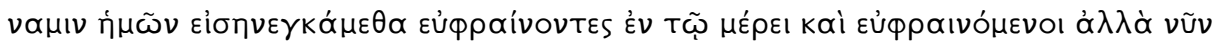


(Melet GNO IX 442, 18-443, 6)

(With what an opposite meaning, as compared with those of late, are our words uttered in this place now! Then we rejoiced with the song of marriage, now we give way to piteous lamentation for the sorrow that has befallen us! Then we chanted an epithalamium, but now a funeral dirge! You remember the day when we entertained you at the feast of that spiritual marriage, and brought home the virgin bride to the house of her noble bridegroom; when to the best of our ability we proffered the wedding gifts of our praises, both giving and receiving joy in turn. But now our delight has been changed to lamentation, and our festal garb become sackcloth) (Trans. Schaff - Wace 1976, 510 [964])

At the beginning of the speech given on the occasion of the death of the bishop of Antioch, however, an image of not just any feast in general but an entirely metaphoric likeness of a wedding party is conjured up, letting the listeners associate not only to the gesture of offering a banquet but also to the feeling of joy relatable to a peculiar liminal life situation. Accordingly, the crowd at the First Council of Constantinople before the unexpected death of Meletius was a rejoicing wedding party but it has evolved into throngs of mourners by today. This metaphor, as one of the similes of the prooemium, serves the purpose of a long lamentation in the oration defined both as paramythetikos logos and epitaphios, ${ }^{49}$ and depicts the unexpected and tragic turn of events in the situation of the council. The image of the wedding party returns at a later stage in the speech but, while in the former instance, Meletius, just like Christ, is present as a bridegroom, he becomes a bride (nymphe) in the latter, longing faithfully for her Lord all the while (Melet GNO IX 450, 2-451, 11) and treating her followers again and again to a spiritual banquet (Melet GNO IX 451, 8: logike pandasia). Both similes display the desire behind the process of idealization; namely, that Meletius should be presented as an "ideal Cristian," the bishop symbolizing (the) unity (of the council).

When we take a separate closer look at the rhetorical figure of the contrast connected to the image of banqueting (yesterday and today/then and now) in the examples above, we need to note first of all that there is no point in examining binary oppositions or dichotomies as rhetorical figures or techniques that could be considered crucial in answering questions on date(s) of delivery. This is partly because these rhetorical-poetical figures are especially typical of the works of the Cappadocian Father on the one hand. On the other hand, they can never exist "on their own": they always occur only as the opposite or the reverse of something else. Typical examples for illustrating this could be Greg-

\footnotetext{
${ }^{49}$ For an analysis of this oration from a different aspect, see Gantz 2002, 139-150.
} 
ory's speeches delivered on the occasion of the death of the daughter, Pulcheria, and the wife, Flacilla, of Emperor Theodosius I. In these speeches, which serve as expressions of Christian mourning as well as imperial rhetoric,${ }^{50}$ binary oppositions sometimes become paradoxes, like in the case of mentioning the simultaneous presence and absence of the dead person: the deceased person is already in heaven, though the earthly remains of her body are still physically close to us (Flacill GNO IX, I 483, 19-484, 2; cf. Pulcher GNO IX, 1 465, 611.; Theod GNO X, 1/2 62, 13-63,1). The number of examples related to opposites and paradoxes taken from the two orations delivered in Constantinople could be further extended. ${ }^{51}$

In the circle of the speeches mentioned above, there seem to be no other examples apart from the two homilies (Steph I, Melet) for using the banquetmetaphor connected to the figures of yesterday and today/then and now, located at the beginning of Mart $I b$. However, we can expand our scrutiny of other speeches by Gregory to cover De deitate adversus Euagrium (Vulgo In suam ordinationem $),{ }^{52}$ delivered on the anniversary of his own ordination in Constantinople, which is conventionally dated back to 381 , despite contrary opinions.

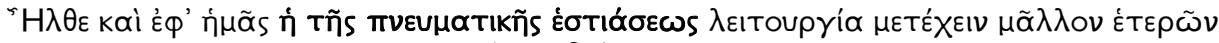

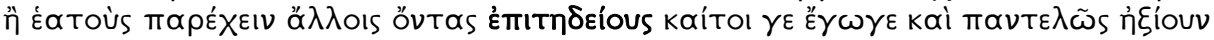

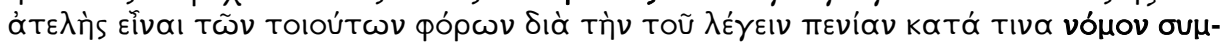
Trotikóv ... (Deit Euag GNO IX, $1331,4-8$ )
}

(The celebration of a spiritual feast has come upon us in order that we partake of benefits other than those which please ourselves. I certainly have considered myself imperfect in such tributes because of my inability to speak, a fact which is in accord with the custom of drinking songs.) (Trans. http://www.documentacatholicaomnia.eu/04z/z_0330-0395_Gregorius_Nyssenus Concerning_His_Own_Ordination_EN.doc.html)

The simile in the opening lines of the prooemium of the speech refers expressly to the figurative, spiritual (pneumatikos) nature of the banquet by equating the spiritual banquet with the speech itself and, when Gregory states that he is not suitable to give a banquet, he actually uses the classic rhetorical topos identified as "pretended modesty/unpreparedness" (Deit Euag GNO IX, 1331 , 6-11). In contrast to the vulgar title (In suam ordinationem), the text of the speech is not about ordination, but the image of the spiritual banquet still acts

\footnotetext{
${ }^{50}$ Holum 1982; Gantz 1999.

${ }^{51}$ Yet, we will find that the banquet-image does not play an important part in these, unless we take the banquet related to the story of Job in the homily about Pulcheria, which is not a simile in this case but a narrative element of the story of Job (Pulcher GNO IX, 1 469, 20ff.).

${ }^{52}$ De deitate adversus Euagrium (Vulgo In suam ordinationem) - Deit Euag GNO IX, 1331 , 4-341, 12.
} 
as an association to the extraordinary quality of the occasion, which is also confirmed by the fact that the expression "good and rich lord of the banquet" mentioned in 331, 13 is certainly an allusion to the person of Meletius, the head of the council. ${ }^{53}$

Despite the scarcity of examples, the temporal proximity of the above orations (Mart Ib, Steph I, Melet, Deit Euag) allows for the assumption that Gregory of Nyssa was in favour of using the metaphor of banquets in his speeches delivered at the beginning and towards the middle of the 380s. This assumption may be further confirmed if we move out of the circle of orations and take a look at pieces written in other genres by the Cappadocian Father around the same time period. Paul J. Alexander has already done that in his study focusing on three pieces of writing by Gregory, De infantibus qui praemature abripiuntur (Infant GNO III, 2 67-97), De hominis opificio (Op hom PG 44, 125-256), and In Ecclesiasten (Ecc GNO V 277-442), from the aspect of how the author adopts a peculiar version of the banquet-image in which the banquet appears as the metaphor of the created world and earthly life of man (simile of the banquet of life).$^{54}$ Nevertheless, he does not attribute the same meaning to the banquetimages in the three pieces, despite their similarity in a lot of respects.

De hominis opificio (Op hom PG 44, 125-256; beginning of 379), which is based also on the Philonic tradition (De opificio mundi) to a great extent, ${ }^{55}$ discusses the motif in Genesis (Gen 1,1-2,4a) that elaborates on the issue of why man was created last. Gregory Nyssen uses the image in respect to the relationship between the Creator and the creature: in the act of creation, God prepares the world for man, as if it was a neatly laid table, invites him to take a seat at this table and, basically, acts like a good host (tis agathos hestiator) (Op hom 2 PG 44, 133C). The simple image in this case is supposed to show "God's providential care for man"; i.e., God's providential governance of the world. ${ }^{56}$

As regards Homily VIII of In Ecclesiasten, a work dated back to several points in time between 378 and $381,{ }^{57}$ Gregory deploys the image with a similar meaning while commenting on verses 3,10ff. in Ecclesiastes, but he also emphasizes the responsibility of the guest (man who has been created) in respect to whether the latter will behave himself at the banquet ( $E c c$ GNO V, 438ff.).

\footnotetext{
${ }^{53}$ Moutsoulas 2010, 214.

${ }^{54}$ Alexander 1976, 55-62.

${ }^{55}$ Alexander 1976, 61-62.

${ }^{56}$ Alexander 1976, 58-59.

${ }^{57}$ Maraval 2010, 158.
} 
The responsibility of man concerning evil in this world appears in a peculiar context in De infantibus, conventionally dated back to $386,{ }^{58}$ inasmuch as one of the main questions in the treatise concerns the relationship between children who die early and sins committed or possible to be committed by people. In the thoroughly elaborated banquet-simile, God is present not simply as a loving host, but more like a chairman of the series of events at the banquet, who has the power of judging the participants and, if necessary, dismissing them so that they would not be able to commit any impropriety. Gregory interprets this latter authority to be the manifestation/consequence of perfect providence when he identifies those who are dismissed (ahori) from the banquet (symposion) with the children who die before their time (GNO III, $267,4-97$, 9; here: 88, 9ff.). ${ }^{59}$

$$
* * *
$$

My initial query about whether we can observe the repetition of certain tropes and rhetorical figures in the chronologically close texts of Gregory of Nyssa, does not seem to be lacking relevance in the case of the banquet-simile. In the pieces written between 379/80 and 386 in different genres and on the basis of different expectations inherent in said genres, the images of feasts and banquets, consistently used in a symbolic sense, do recur every now and then. These rhetorical-poetical solutions, which are similar to one another in a number of respects, might be evoked in the speeches by the similarity of the situations, i.e., the solemn festive quality of the occasions, or the (graceful) condition that can be thematized as a consequence of the gesture of being treated to a banquet.

The symbolic content of banquets displays similarities in several respects in the texts examined: it always represents the uniqueness and ceremonial quality of the occasion, (even when the homily itself is identified with the banquet), as well as the grace that those who are invited can share and, explicitly or implicitly, the possibility of a choice on the part of those invited regarding how they relate to the specific festive occasion.

On the basis of the above, the banquet-image at the beginning of Mart Ib as an argument in textual criticism seems to be appropriate in providing a solution for the dilemmas concerning the identification of the dates of delivery of Mart $I a$ and $I b$, and appears to confirm the conventional assumptions that date the Sebaste homilies back to 380 , or even 383 , as opposed to Leemans, who argues

\footnotetext{
${ }^{58}$ Recent research findings would date it back to 381 and, together with De hominis opificio (beginning of 379) and De anima et resurrectione (end of 379/380), consider it an effort to find answers to questions of anthropology. Cf. Maturi 2010, 421-422.

${ }^{59}$ Alexander 1976, 56-58.
} 
for the time period of Gregory's exile (375/6-378) as the correct date, supposing a stay in Sebaste at that time, which may not be authenticated. ${ }^{60}$

At the same time, there are also arguments against the conventional date (of 383) even beyond those listed by Leemans. Preeminently, one that purports the necessity to examine the use of banquet-similes in works created before 379 , too. These, however, are extant to us to a much lesser extent than those produced after $379 .{ }^{61}$ There could be several reasons for this, among which the most important seems to be that, following the death of his brother, Basil (traditionally dated January 1,379), Gregory engaged in much more intense ecclesiastical activities than before, not least because he also inherited his brother's copists (copiers), which made it possible for him to have his works duplicated in more copies. Furthermore, an investigation of Gregory's overall style beyond just the banquet-simile would be desirable, too, in order to see which of his typical tropes and rhetorical figures could be also considered in the process of determining the dates of production of his works.

\section{Bibliography}

Alexander $1976=$ Alexander, P. J.: Gregory of Nyssa and the Simile of the Banquet of Life. Vigiliae Christianae, 55-62.

Bálint 1977 = Bálint, S.: Ünnepi kalendárium I (Calendar of Religious Feasts I). Budapest.

Bernardi 1968 = Bernardi, J.: La prédication des Pères Cappadociens. Le prédicateur et son auditoire. Paris.

D. Tóth $2016=$ D. Tóth, J.: Az emlékezet retorikája. Nyssai Szent Gergely első homíliája a sebastéi negyven mártír magasztalására (The Rhetoric of Memory. St. Gregory of Nyssa's First Homilies on the Forty Martyrs of Sebaste). In: Bitskey, I. - Fazakas, G. T. - Luffy, K. - Száraz, O. (ed.): In via eruditionis: Tanulmányok a 70 éves Imre Mihály tiszteletére. Debrecen, 409-422.

Daniélou 1955 = Daniélou, J.: La chronologie des sermons de Grégoire de Nysse. Revue des Sciences Religieuses 4, 346-372. = http://www.persee.fr/doc/rscir_0035-2217_1955_num _29_4_2093.

- 1966 = Daniélou, J.: La chronologie des œuvres de Grégoire de Nysse. StPatr 7, 159-169.

Gantz 1999 = Gantz, U.: Gregor von Nyssa: Oratio Consolatoria in Pulcheriam. (Chrêsis. Die Methode der Kirchenväter im Umgang mit der antiken Kultur 6). Basel.

- 2002 = Gantz, U.: Gregory of Nyssa's Encomium of Meletius (GNO 9, 445, 14/446, 17) as an Example of Christian Chrêsis. In: Alvarium. Festschrift für Christian Gnilka. Hrsg. von Blümer, W. - Henke, R. - Mülke, M. (Jahrbuch für Antike und Christentum Ergänzungsband 33). Münster, 139-150.

GNO = Jaeger, W. (ed.): Gregorii Nysseni Opera. Leiden, 1921-.

\footnotetext{
${ }^{60}$ Leemans 2001, 93-97.

${ }^{61}$ The first extant piece written by Gregory is considered to be one De virginitate (Virg GNO VIII, $1247-343)$, dating back approximately to 371.
} 
Holum 1982 = Holum, K. G.: Theodosian Empresses: Women and Imperial Dominion in Late Antiquity. (The Transformation of the Classical Heritage 3). Berkeley-Los Angeles.

Klock 1987 = Klock, Ch.: Untersuchungen zu Stil und Rhythmus bei Gregor von Nyssa. Ein Beitrag zum Rhetorikverständnis der griechischen Väter. Frankfurt am Main.

Leemans 2001 = Leemans, J.: On the Date of Gregory of Nyssa's First Homilies on the Forty Martyrs of Sebaste (Mart Ia and Mart Ib). Journal of Theological Studies 52, 93-97.

- 2003 = Leemans, J. - Mayer, W. - Allen, P. - Dehandschutter, B. (eds.): „Let us Die That We May Live". Greek Homilies on Christian Martyrs from Asia Minor, Palestine and Syria (c. $A D$ 350-AD 450). London-New York, 91-110.

- 2005 = Leemans, J.: Style and Meaning in Gregory of Nyssa's Panegyrics on Martyrs. Ephemerides Theologicae Lovanienses 1, 109-129.

— 2010a = Leemans, J.: Mart Ia. Mart Ib. In: Mateo-Seco, L. F. - Maspero, G. (eds.) - Cherney, S. (trans.): The Brill Dictionary of Gregory of Nyssa. Leiden-Boston, 483-486.

$-2010 \mathrm{~b}=$ Leemans, J.: Reading Acts 6-7 in the Early Church: Gregory of Nyssa's First and Second Homilies on Stephen the Protomartyr. StPatr 47, 9-19.

Lendle 1990 = Heil, G. - Cavarnos, J. P. - Lendle, O. (eds.): Gregorius Nyssenus Sermones. Pars II (Gregorii Nysseni Opera X, 1/2). Leiden.

Limberis 2011 = Limberis, V. M.: Architects of Piety. The Cappadocian Fathers and the Cult of the Martyrs. Oxford.

Mann 1999-2014 = von Mann, F. (Bearb.): Lexicon Gregorianum. Wörterbuch zu den Schriften Gregors von Nyssa. Vol. I-X. Leiden.

Maraval $1990=$ Maraval, P. (trad.): Lettres. (Sources Chrétiennes 363). Paris.

- $2004=$ Maraval, P.: Retour sur quelques dates concernant Basile de Césarée et Grégoire de Nysse. Revue d'histoire ecclésiastique, 153-157.

- $2010=$ Maraval, P.: Chronology of Works. In: Mateo-Seco, L. F. - Maspero, G. (eds.) Cherney, S. (trans.): The Brill Dictionary of Gregory of Nyssa. Leiden-Boston, 153-169.

Mateo-Seco - Maspero $2010=$ Mateo-Seco, L. F. - Maspero, G. (eds.) - Cherney, S. (trans.): The Brill Dictionary of Gregory of Nyssa. Leiden-Boston.

Maturi 2010 = Maturi, G.: De infantibus praemature abreptis. In: Mateo-Seco, L. F. - Maspero, G. (eds.) - Cherney, S. (trans.): The Brill Dict. of Gregory of Nyssa. Leiden-Boston, 421-422.

May 1971 = May, G.: Die Chronologie des Lebens und der Werke des Gregor von Nyssa. In: Harl, M. (éd.): Écriture et culture philosophique dans la pensée de Grégoire de Nysse. Actes du Colloque de Chevetogne (22-26 Septembre 1969). Leiden, 51-67.

Meredith 2003 = Meredith, A.: Gregory of Nyssa. Taylor \& Francis e-Library.

Moutsoulas $2010=$ Moutsoulas, E.: De deitate adversus Evagrium. In: Mateo-Seco, L. F. - Maspero, G. (eds.) - Cherney, S. (trans.): The Brill Dict. of Gregory of Nyssa. Leiden-Boston, 214-215.

Murray, O. (ed.): Sympotica. A Symposium on the Symposion. Oxford.

Mühlenberg, E.: Gregor von Nyssa über die Vierzig und den ersten Märtyrer (Stephanus). In: Gemeinhardt, P. - Leemans, J. (eds.): Christian Martyrdom in Late Antiquity. History and Discourse, Tradition and Religious Identity. Berlin-Boston, 115-134.

Schaff - Wace 1976 = Schaff, Ph. - Wace, H. (Eds.): A select library of Nicene and Post-Nicene Fathers of the Christian Church, Series II, Vol. V, Gregory of Nissa: Dogmatic Treatises; Select Writings and Letters. Christian Classics Ethereal Library. Grand Rapids, Mi, 509-513. cf. www.ccel.org/ccel/schaff/npnf205.pdf, 963-972.

Silvas 2007 = Silvas, A. M. (ed.): Gregory of Nyssa: The Letters. Introduction, Translation and Commentary. (Supplements to Vigiliae Christianae. Formerly Philosophia Patrum, Vol. 83). Leiden-Boston, 1-58.

(ISSN $0418-453 X)$ 